physical health of children all while describing the various ways that one can work with children along with some of the challenges that the experts face each day along with some of the children's experiences.

\section{PEDIATRICIAN AND EDUCATIONAL REHABILITATOR - ASSOCIATES IN THE PROCESS OF OBSERVATION, DIAGNOSIS AND REHABILITATION OF CHILDREN WITH DEVELOPMENTAL DISABILITIES}

${ }^{1}$ Marija Presečki Zmajlović*, ${ }^{1}$ Presečki Zmajlović, ${ }^{2}$ Mara Modrić, ${ }^{3}$ Ivan Razum. ${ }^{1}$ Kindergarten Radost, Jastrebarsko, Croatia; ${ }^{2}$ Elementary School Sesvetska Sopnica, Sesvete, Croatia; ${ }^{3}$ Health Center Jastrebarsko, Croatia

10.1136/archdischild-2021-europaediatrics.23

The number of children with disabilities and persons with disabilities is continuously increasing, which is evident from the data of the Croatian Institute of Public Health. The report on persons with disabilities in the Republic of Croatia, May 2019, lists 45,314 children with disabilities. The pediatrician, as a doctor who deals with the health care of children from birth to the end of adolescence and cares about improving the child's health and eliminating risk factors that threaten his normal growth and development, certainly has children with disabilities and developmental difficulties among his patients. An important part of any systematic examination of a child should be an assessment of psychomotor development and monitoring developmental milestones. When it comes to children with disabilities it can also include information obtained from co-specialists. The competencies of pediatricians include the promptly detection of developmental dilays, knowledge of various developmental disabilities, and also perspective of related co-experts within different systems.

In providing support to children with disabilities, educational rehabilitators are important part of the interdisciplinary diagnostic team, the team of early intervention experts and professional teams in kindergartens and schools. They are a profession whose diagnostic, educational and rehabilitation procedures and programs apply to children with disabilities and persons with disabilities, the population with visual impairment, learning difficulties, attention deficit hyperactivity disorder, motor disorders, chronic diseases and multiple disabilities. The actions of both, the pediatrician and the educational rehabilitator, are aimed at the well-being of the child with risk factors, developmental delays or identified developmental difficulties. Mutual cooperation should include the exchange of key information and trust in the assessment, competencies and recommendations.

It is particularly important in case of children with autism spectrum disorder, which is primarily characterized by difficulties in social communication and interaction and limited, repetitive patterns of behavior, interests, and activities. During the periodic systematic examination in the pediatric clinic, the mere presence of the parents and the learned strategies can mask the characteristic difficulties. In some children, symptoms are present at an early stage of development, but often become more apparent when social demands exceed the child's current abilities. They are more pronounced during the child's time in kindergarten or school, which is then noticed by other professional associates - educational rehabilitator.

If the parent is not concerned about the child's development, finds it difficult to accept the possibility of the difficulty or denies it, sometimes is missing the transfer of key informations in sequence, ,educational rehabilitator - parent - pediatrician', which unfortunately slows down the process of diagnosis and intervention. As an example of good practice and cooperation between a pediatrician and an educational rehabilitator for the purpose of objective informing, we provide and recommend a written opinion about the developmental status of the child.

\section{PRESENCE OF LANGUAGE DISORDERS IN SCHOOL AGE}

Martina Galeković*. Centar za odgoj i obrazovanje Velika Gorica

10.1136/archdischild-2021-europaediatrics.24

Language difficulties refer to impaired language acquisition and impaired language processing and can be an integral part or one of multiple difficulties. The most common among them is developmental language disorder, which refers to the present difficulties in the domain of language. Developmental language disorder is diagnosed when a child, despite orderly general cognitive abilities and a stimulating environment, has difficulty learning his mother tongue, and then any other language.

The paper presents the results of the analysis of the presence of developmental speech disorder in users of psychosocial support services in the Zagreb County. Linguistic comprehension was examined and the obtained results were analyzed by a qualitative methodology.

We emphasize the awareness of parents, professionals and all those involved in the upbringing and education of the child as a prerequisite for partnership with students and providing the necessary support to students in working with difficulties in the field of language comprehension.

\section{General Pediatrics}

\section{CHILD'S BLOOD VESSEL DEVELOPMENT IN RELATION TO MOTHER'S DIETARY EATING HABITS AND ORAL HEALTH}

Senka Mesihovic Dinarevic ${ }^{*}$, Anes Jogunčić, Kristen Sarić, Lutvo Sporišević, Berislav Topić, Vjekoslav Krželj, Liana Cambj-Sapunar, Davor Petrović, Sanja Jurišić, Senad Sarić, Samir Prohić. Polyclinic Eurofarm

\subsection{6/archdischild-2021-europaediatrics.25}

Dietary eating habits and oral health of pregnant women have the potential to affect pregnancy outcomes. Some observational studies have indicated a significant association of the periodontal disease with adverse pregnancy outcomes, such as the risk of preterm delivery and differences in blood vessels development.

The aim of the study was to evaluate the relationship between the dietary eating habits of mothers and their oral health during pregnancy with the development of the coronary and carotid arteries including intima media thickness.

By random selection, 40 pregnant women and their newborns formed a cohort - pilot study. The approval of the ethics committee was obtained. During pregnancy eating habits and dental mother's status were analyzed. After delivery, a 